INSPIRAMATIKA | Jurnal Inovasi Pendidikan dan Pembelajaran Matematika Volume 6, Nomor 2, Desember 2020, ISSN 2477-278X, e-ISSN 2579-9061

\title{
PERBANDINGAN MOTIVASI BELAJAR SISWA MENGGUNAKAN PRODUK PENGEMBANGAN BAHAN AJAR BENTUK SURAT KABAR DENGAN LEMBAR KERJA SISWA (LKS)
}

\author{
Silvi Apipatus Saadah ${ }^{\mathrm{a}}$, Hendri Raharjo ${ }^{\mathrm{b}}$, Arif Muchyidin ${ }^{\mathrm{c}}$ \\ ${ }^{a}$ Pendidikan Matematika FITK IAIN Syekh Nurjati Cirebon \\ J1. Perjuangan By Pass Sunyaragi, Cirebon, silviapipatus@syekhnurjati.ac.id \\ ${ }^{\mathrm{b}}$ Pendidikan Matematika FITK IAIN Syekh Nurjati Cirebon \\ Jl. Perjuangan By Pass Sunyaragi, Cirebon, hendri_raharjo@syekhnurjati.ac.id \\ ${ }^{c}$ Pendidikan Matematika FITK IAIN Syekh Nurjati Cirebon \\ Jl. Perjuangan By Pass Sunyaragi, Cirebon, muchyidin@ syekhnurjati.ac.id
}

\begin{abstract}
ABSTRAK
Tujuan dilakukannya penelitian pengembangan ini adalah untuk mendeskripsikan produk pengembangan bahan ajar matematika ke dalam bentuk surat kabar dan untuk mengetahui perbandingan motivasi belajar siswa yang menggunakan bahan ajar bentuk surat kabar dengan siswa yang menggunakan Lembar Kerja Siswa (LKS). Jenis penelitian yang digunakan adalah Research and Development (R\&D) dengan model pengembangan ADDIE yang merupakan kepanjangan dari Analysis, Design, Development, Implementation, Evalution dan pada tahap uji coba lapangan peneliti menggunakan rancangan eksperimental sungguhan (True Experimental Design) dalam rancangan ini, terdapat dua kelompok yaitu satu kelompok memperoleh perlakuan eksperimen. Kedua kelompok diberikan pascauji tetapi tidak diberikan prauji. Teknik analisis data yang digunakan adalah Uji $\mathrm{T}$ Independent. Berdasarkan hasil penelitian, produk bahan ajar ini layak untuk digunakan sebagai bahan ajar di kelas terbukti dari hasil validasi para ahli. Pada validasi materi diperoleh persentase kelayakan mencapai 90,5\% dan persentase kelayakan untuk validasi ahli desain mencapai 95,83\% serta persentase kelayakan yang diperoleh dari respon siswa mencapai 86,77\%. Persentase pencapaian ketiganya berada pada klasifikasi layak untuk digunakan dalam pembelajaran. Untuk motivasi belajar siswa kelas eksperimen diperoleh rata-rata 124,68 sedangkan motivasi belajar siswa kelas kontrol memperoleh rata-rata 116,04. Hasil perhitungan uji-t dari rata-rata motivasi belajar kelas eksperimen dan kontrol, Sig. (2-tailed) menghasilkan angka 0,001. Hasil nilai Sig. (2-tailed) tersebut <0,05. Hal ini menunjukkan bahwa $H_{0}$ ditolak dan $H_{1}$ diterima, artinya terdapat perbedaan yang signifikan antara motivasi belajar kelas ekperimen dan kontrol. Motivasi belajar siswa dengan menggunakan produk bahan ajar bentuk surat kabar dalam pembelajaran lebih baik dari motivasi belajar siswa menggunakan bahan ajar lembar kerja siswa (LKS).
\end{abstract}

Kata Kunci : Bahan ajar, surat kabar, lembar kerja siswa, motivasi belajar.

\begin{abstract}
The purpose of this development research is to describe the product development of mathematics teaching materials in the form of newspapers and to compare the learning motivation of students using newspaper-form teaching materials with students using Student Worksheets (LKS). The method used is the type of Research and Development ( $R \& D)$ research with the ADDIE development model which stands for Analysis, Design, Development, Implementation, Evalution and at the field trial stage the researchers used a real experimental design in this design, there are two groups namely one group obtained experimental treatment. Both groups were given post-test but were not given pre-
\end{abstract}


test. The data analysis technique used is the Independent $\mathrm{T}$ Test. Based on the results of the study, this teaching material product is feasible to be used as teaching material in the classroom as evidenced by the results of the validation of experts. In the material validation, the percentage of eligibility reached $90.5 \%$ and the percentage of eligibility for design expert validation reached $95.83 \%$ and the percentage of eligibility obtained from student responses reached $86.77 \%$. The percentage of achievement of the three is in the proper classification for use in learning. For students' learning motivation the experimental class obtained an average of 124.68 while the learning motivation of control class students gained an average of 116.04. The t-test calculation results from the average learning motivation of the experimental and control classes, Sig. (2-tailed) produces a number of 0.001 . The results of the Sig. (2-tailed) $<0.05$. This shows that $H_{0}$ is rejected and $H_{1}$ is accepted, meaning that there is a significant difference between the experiment class motivation and control. Motivation of student learning by using teaching materials in the form of newspapers in learning is better than students' learning motivation using teaching materials student worksheets (LKS).

Keyword(s): Learning materials, newspaper, student worksheets, motivation to learn.

\section{PENDAHULUAN}

Penguasaan mata pelajaran matematika sangatlah penting dalam rangka meningkatkan mutu sumber daya manusia. Wajar bila mata pelajaran matematika ini mulai diperkenalkan sejak sekolah dasar bahkan sejak taman kanak-kanak. Melihat begitu pentingnya matematika, maka pembelajaran matematika harus mencapai keberhasilan. Untuk itu, potensi yang meliputi aspek kognitif, afektif, maupun psikomotorik anak perlu dikembangkan. Salah satu yang berperan penting dalam mengembangkan potensi anak tersebut yaitu proses pembelajaran. Menurut Depdiknas (2008) ada empat hal yang terkait dalam proses pembelajaran yaitu perencanaan, pelaksanaan, penilaian, dan pengawasan. Perencanaan pembelajaran merupakan acuan dalam membuat target pencapaian keberhasilan pembelajaran. Kompetensi yang hendak dicapai disajikan dalam perencanaan pembelajaran kemudian dirancang metode, strategi, sumber belajar, bahan ajar, dan instrumen penilaian yang digunakan untuk mengukur ketercapaian kompetensi tersebut. Maka dari itu, sangat diperlukan sebuah perencanaan pembelajaran yang matang dalam proses pembelajaran matematika.

Selain itu, dalam proses pembelajaran minat merupakan sebuah awal penggerakan untuk peserta didik dalam belajar yang dapat digunakan untuk mencapai tujuan yang diinginkan (Ammi Fauziah, 2017). Hal tersebut menggambarkan jika seseorang memiliki minat belajar dalam dirinya maka dia akan mencapai keinginanya. Dengan demikian, minat terhadap belajar sangat diperlukan dalam pembelajaran agar peserta didik memiliki ketertarikan terhadap materi yang 
diajarkan. Ammi dkk (2017) mengatakan bahwa selain minat, peserta didik juga memerlukan dorongan atau gerakan untuk mencapai tujuan pembelajaran. Dorongan ini disebut dengan motivasi, di dalam motivasi juga terdapat keinginan dan citacita yang tinggi sehingga peserta didik yang memiliki motivasi belajar akan mengerti dengan apa yang menjadi tujuan dalam belajar dan akan semangat dalam belajar dapat menyelesaikan tugas dengan baik. Peserta didik yang memiliki motivasi belajar maka akan serius dan tertarik dalam pembelajaran sehingga peserta didik mendapatkan hasil belajar yang memuaskan. Hal itulah yang senantiasa diharapkan terjadi pada peserta didik dalam pembelajaran mata pelajaran matematika.

Kenyataannya justru yang terjadi adalah sebaliknya. Keluhan dan kekecewaan terhadap hasil yang dicapai peserta didik dalam matematika hingga saat ini sering diungkapkan. Pada umumnya peserta didik mengatakan bahwa pelajaran matematika adalah pelajaran yang sulit dan membosankan, soal matematika itu sulit, tingkat kesulitan soal yang sering dihadapi berbeda dengan yang diterangkan oleh guru di kelas dan akhirnya nilai yang mereka dapat rendah sehingga minat terhadap pelajaran matematika tidak ada dan hasil belajar matematika pun rendah. Keluhan peserta didik kepada mata pelajaran matematika ini terlihat dari hasil Survei Programme for International Student Assessment (PISA) yang dilakukan oleh Organisasi Kerja Sama Ekonomi dan Pembangunan (OECD) pada tahun 2015 silam, menempatkan kemampuan matematika pelajar Indonesia berada di peringkat ke-63 dari 72 negara (Gewati, 2018). Banyak dari mereka ketika dalam proses pembelajaran di kelas mereka lebih memilih tidak memperhatikan apa yang disampaikan oleh guru dan mengalihkan perhatian mereka pada hal lain selain pembelajaran, seperti berbicara dengan teman sebangkunya, tidur, melamun, bermain sendiri, dan sebagainya. Belum lagi ditambah sering kali guru meninggalkan kelas karena ada urusan seperti rapat guru ataupun masalah pribadi, maka untuk mengelola kelas agar tetap terkendali, guru menggunakan Lembar Kerja Siswa (LKS) yang saat ini banyak digunakan di sekolahsekolah. Namun demikian, yang terjadi bukan kelas yang terkontrol justru kelas yang semakin tidak terkontrol. Peserta didik justru malah leluasa bermain ketimbang mengerjakan atau mempelajari materi ajar yang terdapat pada LKS. 
Rendahnya motivasi belajar siswa terhadap pelajaran matematika salah satu penyebabnya. Tidak ada dukungan, kurangnya keinginan dalam diri peserta didik untuk mempelajari dan memahami matematika dengan sungguh-sungguh. Kesadaran bahwa pelajaran matematika itu penting belum sepenuhnya melekat dalam diri mereka. Telah disinggung sebelumnya bahwa untuk mencapai tujuan pembelajaran diperlukannya suatu motivasi atau dorongan terhadap belajar, khususnya di sini motivasi terhadap belajar matematika. Motivasi sendiri merupakan salah satu faktor yang sangat penting untuk mendorong semangat belajar peserta didik. Salah satu yang dapat berperan sebagai pendorong bagi peserta didik adalah guru. Proses pembelajaran akan berhasil manakala siswa mempunyai motivasi dalam belajar oleh karena itu seorang guru perlu menumbuhkan motivasi belajar siswa, untuk memperoleh hasil belajar yang optimal guru dituntut kreatif membangkitkan motivasi belajar siswa karena dengan guru kreatif menjadikan siswa tergugah dalam pembelajaran yang akan dialami siswa atau siswa yang sedang mengikuti proses pembelajaran (Suprihatin, 2015). Perannya sebagai guru di sekolah, lewat proses pembelajaranlah seorang guru berkesempatan menumbuhkan motivasi belajar peserta didik. Prinsip mengajar itu sendiri adalah mempermudah dan memberikan motivasi belajar kepada peserta didik, sehingga guru sebagai pengajar memiliki tugas memberi fasilitas atau kemudahan bagi peserta didik dalam kegiatan pembelajaran. Berkaitan dengan itu, proses pembelajaran harus dikemas sedemikian rupa dan dipersiapkan sebaik mungkin agar dapat menarik perhatian peserta didik sehingga dapat tercapai tujuan daripada pembelajaran matematika itu sendiri. Salah satunya, dapat dilakukan dengan memberikan inovasi-inovasi pembelajaran. Inovasi-inovasi tersebut dirancang sebelumnya dalam perencanaan pembelajaran. Salah satu bentuk usaha dalam rangka meningkatkan motivasi belajar peserta didik yaitu dengan mengembangkan suatu bahan ajar. Lestari (2013) mengatakan dalam bukunya bahwa bahan ajar merupakan sumber belajar yang memiliki peranan penting untuk menunjang proses pembelajaran, kualitas bahan ajar yang rendah dengan pembelajaran konvensional akan berakibat rendahnya perolehan prestasi belajar siswa. Bahan ajar yang saat ini banyak digunakan di sekolahsekolah yaitu berupa LKS (Lembar Kerja Siswa). LKS yang saat ini beredar di sekolah kurang menarik perhatian peserta 
didik baik dari segi sajian materi ataupun tampilannya. Setelah melakukan perbincangan dengan guru sekolah, sampai saat ini guru masih jarang menyusun bahan ajar sendiri. Bahan ajar yang digunakan di sekolah biasanya LKS yang dijual di pasaran. Menurut Andi Prastowo (2016) bagi siswa jika bahan ajar yang dibuat itu bervariasi, inovatif, dan menarik maka paling tidak ada tiga kegunaan bahan ajar bagi peserta didik yaitu pertama kegiatan pembelajaran menjadi lebih menarik, kedua akan lebih banyak mendapatkan kesempatan untuk belajar secara mandiri dengan bimbingan pendidik, dan ketiga akan mendapat kemudahan dalam mempelajari setiap kompetensi yang harus dikuasainya. Maka dari itu, diperlukan suatu pengembangan bahan ajar yang dapat digunakan dalam proses pembelajaran yang akan menarik perhatian peserta didik, dalam rangka untuk meningkatkan motivasi belajar mereka terhadap mata pelajaran matematika. Berdasarkan permasalahan yang ada di lapangan, maka penulis tertarik untuk melakukan pengembangan terhadap bahan ajar. Bahan ajar yang disusun dikembangkan dalam bentuk surat kabar. Surat kabar sendiri sering dijadikan sebagai salah-satu bahan ajar yang baik dalam bentuk kliping maupun dalam bentuk lembaran-lembaran yang dipotong sesuai dengan kebutuhan pembelajaran, pemberitaan yang dimuat dalam surat kabar dapat dijadikan sumber belajar yang dipilih berdasarkan relevansinya dengan pokok bahasan tertentu.

Tujuan penelitian ini adalah (1) untuk mendeskripsikan produk pengembangan bahan ajar matematika ke dalam bentuk surat kabar, (2) mengetahui perbandingan motivasi belajar siswa yang menggunakan bahan ajar bentuk surat kabar dengan siswa yang menggunakan Lembar Kerja Siswa (LKS).

\section{METODE PENELITIAN}

Jenis penelitian yang digunakan dalam penelitan yang dilakukan adalah metode penelitian Research and Development (R\&D). Menurut Sugiyono (2017) metode penelitian dan pengembangan atau dalam Bahasa Inggrisnya Research and Development (R\&D) adalah metode penelitian yang digunakan untuk menghasilkan produk tertentu dan menguji keefektifan produk tertentu. Pada penelitian yang dilakukan ini, metode R\&D akan digunakan untuk menghasilkan produk bahan ajar dalam bentuk surat kabar dan menguji kefektifan bahan ajar tersebut dalam menumbuhkan 
motivasi belajar siswa. Model pengembangan yang digunakan adalah model pengembangan yang pernah dilakukan oleh Robert Maribe Branch dalam mengembangkan Intructional Design (Desain Pembelajaran), yaitu pendekatan ADDIE yang merupakan kepanjangan dari Analysis, Design, Development, Implementation, dan Evalution. Analisys (menganalisis), berkaitan dengan kegiatan analisis terhadap situasi kerja dan lingkungan, dalam kaitannya dengan penelitian yang akan dilakukan ini yaitu terkait kebutuhan peserta didik sehingga dapat ditemukan produk apa yang perlu dikembangkan. Design (mendesain) merupakan kegiatan perancangan produk sesuai dengan kebutuhan, dalam hal ini berupa perancangan produk bahan ajar dalam bentuk surat kabar. Development (mengembangkan) yaitu kegiatan pembuatan atau realisasi produk. Implementation (melaksanakan) kegiatan menggunakan produk. Evalution (menilai) yaitu kegiatan perbaikan atau menilai apakah setiap langkah kegiatan dan produk yang dibuat sudah sesuai dengan spesifikasi atau belum.

Untuk mengetahui kefektifan dan kelayakan bahan ajar yang dikembangkan serta sejauh mana produk yang dibuat dapat mencapai sasaran maka dilakukan penilaian terhadap produk bahan ajar. Bahan ajar yang dikembangkan akan dinilai pada beberapa aspek dalam meninjau apakah isi serta materi telah sesuai dengan kurikulum yang berlaku. Penilaian produk ini, bertujuan untuk mendapat perbaikan agar bahan ajar tersebut layak dan efektif digunakan oleh pendidik dan peserta didik dalam proses pembelajaran. Penilaian produk ini mencakup beberapa kriteria, diantaranya:

Desian uji coba, dilakukan dua tahap, pertama uji ahli (expert judgement) yaitu untuk menguatkan serta meninjau ulang produk awal dan memberikan masukan perbaikan. Kedua uji coba lapangan (field testing) produk diuji cobakan dalam kegiatan pembelajaran bertujuan untuk mendapatkan informasi terkait kelayakan produk bahan ajar. Pada tahap uji ahli atau uji validasi desain dilakukan melalui 2 tahap yaitu (1) validasi ahli materi, bertujuan untuk menguji kelayakan dari segi materi, kesesuaian materi dengan kurikulum serta kesesuaian bahan ajar. Uji ahli materi ini dipilih orang yang kompeten dalam bidang matematika. (2) validasi ahli media/desain, bertujuan untuk mengkaji asfek kegrafikan pada bahan ajar. Pengujian ini dilakukan setelah peneliti menyelesaikan uji coba terhadap ahli materi dan melakukan revisi 
sesuai dengan masukan yang diberikan oleh ahli materi. Pada tahap uji coba lapangan, peneliti menggunakan rancangan eksperimental sungguhan (True Experimental Design) No. 6 Rancangan dengan Kelompok Kontrol hanya Pascauji (Consuelo G Sevilla, 2006). Dalam rancangan ini ada dua kelompok yaitu satu kelompok memperoleh perlakuan eksperimen. Kedua kelompok hanya diberikan pascauji tidak diberikan pra-uji, berikut gambaran rancangan yang digunakan.

$$
\begin{array}{lll}
\mathrm{R} & \mathrm{X} & O_{1} \\
\mathrm{R} & & O_{2}
\end{array}
$$

$\mathrm{R}=$ penetapan secara acak

$\mathrm{X}=$ perlakuan

$O_{1}=$ pascauji eskperimen

$\mathrm{O}_{2}=$ pascauji kontrol

Subjek uji coba, yang menjadi subjek penilaian yaitu ahli materi dan ahli desain, sedangkan subjek uji coba pengguna yaitu siswa kelas VIII semester II MTs Negeri 12 Majalengka. Uji coba ini dilakukan pada dua kelas sebagai sampel penelitian, dengan catatan kesetaraan individu pada kedua kelas terebut. Hal ini diperlukan untuk mengatur variabel-variabel yang mungkin menyebabkan kesimpulan penelitian yang tidak valid, yang membedakan antara kedua kelas tersebut adalah treatmen atau perlakuan. Kelas eksperimen adalah kelas yang mendapat perlakuan yaitu pada proses pembelajaran di uji cobakan produk bahan ajar hasil pengembangan peneliti sedangkan kelas kontrol adalah kelas yang tidak mendapatkan perlakuan yaitu dalam pembelajarannya menggunakan bahan ajar LKS yang telah tersedia sebelumnya.

Instrumen Pengumpulan Data yang digunakan dalam penelitian ini adalah lembar validasi untuk ahli media dan ahli materi, angket respon siswa serta angket motivasi belajar untuk mengukur motivasi belajar siswa.

Teknik analisis data yang digunakan untuk menentukan tingkat kevalidan/kelayakan produk bahan ajar hasil pengembangan, digunakan teknik analisis dengan menggunakan rumus: (Riono, 2016)

$$
P=\frac{\sum X}{\sum X_{i}} \times 100 \%
$$

Keterangan:

$\mathrm{P} \quad=$ Persentase

Kevalidan/kelayakan

$\sum \mathrm{X}=$ Jumlah total skor jawaban validator (nilai nyata)

$\sum X_{i}=$ Jumlah total skor jawaban tertinggi (nilai harapan)

Untuk menentukan tingkat kelayakan/kevalidan serta dasar pengambilan keputusan untuk merevisi 
produk bahan ajar menggunakan kriteria kualifikasi penilaian sebagai berikut. (Riono, 2016)

Tabel 1. Kualifikasi Tingkat Kelayakan Berdasarkan Persentase Rata-rata

\begin{tabular}{|c|c|c|}
\hline Persentase (\%) & Kategori & Ket \\
\hline $\begin{array}{c}84 \%<\text { skor } \leq \\
100 \%\end{array}$ & $\begin{array}{l}\text { Sangat } \\
\text { Layak }\end{array}$ & $\begin{array}{l}\text { Tidak } \\
\text { Revisi }\end{array}$ \\
\hline $\begin{array}{c}68 \%<\text { skor } \leq \\
84 \%\end{array}$ & Layak & $\begin{array}{l}\text { Tidak } \\
\text { Revisi }\end{array}$ \\
\hline $\begin{array}{c}52 \%<\text { skor } \leq \\
68 \%\end{array}$ & $\begin{array}{l}\text { Cukup } \\
\text { Layak }\end{array}$ & $\begin{array}{l}\text { Tidak } \\
\text { Revisi }\end{array}$ \\
\hline $\begin{array}{c}36 \%<\text { skor } \leq \\
52 \%\end{array}$ & $\begin{array}{l}\text { Kurang } \\
\text { Layak }\end{array}$ & $\begin{array}{c}\text { Revisi } \\
\text { sebagian }\end{array}$ \\
\hline $\begin{array}{c}20 \%<\text { skor } \leq \\
36 \%\end{array}$ & $\begin{array}{l}\text { Tidak } \\
\text { Layak }\end{array}$ & Revisi \\
\hline
\end{tabular}

Berdasarkan Tabel 1, maka produk bahan ajar dikatakan valid atau layak jika memenuhi kriteria skor 68 dari seluruh unsur yang terdapat dalam angket penilaian validasi ahli desain, media, dan siswa.

Untuk mengetahui keberhasilan produk bahan ajar pada uji coba lapangan siswa kelas eksperimen (kelas C) apakah terdapat perbedaan rata-rata motivasi belajar yang signifikan dengan siswa kelas kontrol (kelas B) digunakan teknik analisis Uji T Independent. Dalam praktiknya penggunaan uji $\mathrm{t}$ independen ini adalah untuk membandingkan perbedaan rata-rata antara dua kasus, soal-soal atau antara subjek dari kelompok kontrol dan eksperimen, untuk menentukan apakah ada perbedaan rata-rata antara dua kelompok utuh yang berkenaan dengan variabel standar (Consuelo G Sevilla, 2006). Prosedur analisis uji $t$ independen ini meliputi: (Kumaidi, 2014)

1. Penetapan hipotesis

Berikut hipotesis yang akan di uji kan.

$H_{0}$ : Tidak terdapat perbedaan yang signifikan antara motivasi belajar kelas C dan kelas B

$H_{1}$ : Terdapat perbedaan yang signifikan antara motivasi belajar kelas C dan kelas B

2. Penetapan alpha $(\alpha)$

Nilai alpha $(\alpha)$ yang digunakan yaitu $0,05(5 \%)$.

3. Penetapan daerah kritis (BK) melalui penghitungan SE (Standar Eror) atau $\tilde{\sigma}_{\bar{X}_{A}}-\tilde{\sigma}_{\bar{X}_{B}}$

$$
\tilde{\sigma}_{\bar{X}_{A}}-\tilde{\sigma}_{\bar{X}_{B}}=\sqrt{\frac{S_{A}^{2}}{n_{A}-1}+\frac{S_{B}^{2}}{n_{B}-1}}
$$

Harga $Z_{B K}$ atau $t_{\text {tabel }}$ digunakan sebagai batas kritis penerimaan dan penolakan $H_{0}$ dalam bentuk skor standar $\mathrm{z}$ atau $t_{\text {hitung. Harga }} Z_{B K}$ atau $t_{\text {tabel }}$ ini dapat dilihat dari Tabel Distribusi Normal disesuaikan dengan harga $\alpha$ yang digunakan. 
4. Menghitung tes statistik

$$
z \text { atau } t_{\text {hitung }}=\frac{\left(\bar{X}_{A}-\bar{X}_{B}\right)-\left(\mu_{A}-\mu_{B}\right)}{\tilde{\sigma}_{\bar{X}_{A}}-\tilde{\sigma}_{\bar{X}_{B}}}
$$

5. Pengambilan kesimpulan

Pengambilan kesimpulan dapat dilakukan dengan membandingkan harga $\mathrm{z}$ dan harga $Z_{B K}$.

- Apabila nilai $\mathrm{z}$ atau $t_{\text {hitung }}$ positif, maka dikatakan terdapat perbedaan yang signifikan jika $\mathrm{z}$ atau $t_{\text {hitung }}>$ $Z_{B K}$ atau $t_{\text {tabel }}$

- Apabila nilai $\mathrm{z}$ atau $t_{\text {hitung }}$ negatif, maka dikatakan terdapat perbedaan yang signifikan jika z atau $t_{\text {hitung }}<$ $Z_{B K}$ atau $t_{\text {tabel }}$

Selain dengan cara membandingkan harga $z$ atau $t_{\text {hitung }}$ dan $Z_{B K}$ atau $t_{\text {tabel }}$, pengambilan kesimpulan juga dapat menggunakan dasar pengembilan keputusan sebagai berikut.

- Jika nilai Sig. (2-tailed) < 0,05, maka terdapat perbedaan yang signifikan, artinya $H_{0}$ ditolak dan $H_{1}$ diterima.

- Jika nilai Sig. (2-tailed) >0,05, maka tidak terdapat perbedaan yang signifikan, artinya $H_{0}$ diterima dan $H_{1}$ ditolak.

\section{HASIL DAN PEMBAHASAN}

Hasil dari observasi peneliti di lapangan, guru mata pelajaran matematika di MTs Negeri 12 Majalengka masih jarang menyusun bahan ajar sendiri. Selama ini guru melakukan pembelajaran secara konvensional yaitu dengan metode ceramah dan tanya jawab. Serta untuk bahan ajarnya, guru masih menggunakan buku paket dan LKS. Metode seperti ini dinilai hemat dari segi biaya dan juga tidak membutuhkan keahlian khusus bagi guru. Akan tetapi, pembelajaran dengan metode yang konvensional secara terus-menerus dalam pembelajaran akan menimbulkan kejenuhan bagi siswa, sehingga siswa kurang termotivasi dalam mengikuti pembelajaran yang ada di dalam kelas dan dapat berdampak terhadap hasil belajar siswa, ditambah dengan bahan ajar yang tersedia hanya LKS, belum ada bahan ajar lain yang digunakan. Siswa mulai menunjukkan ketidaktertarikan terhadap LKS dan buku paket. LKS yang saat ini beredar di sekolah kurang menarik perhatian peserta didik baik dari segi sajian materi ataupun tampilannya, sehingga siswa mengharapkan adanya bahan ajar yang dapat menunjang pembelajaran dan membantu dalam memahami materi yang sedang dipelajari. 
Pada tahap pengembangan produk kepada ahli materi dan ahli desain/media. bahan ajar, dilakukan kegiatan validasi LKS Hasil pengolahan lembar validasi diperoleh:

Tabel 2. Hasil Validasi Ahli Materi

\begin{tabular}{|c|c|c|c|c|c|c|c|}
\hline No & Validator & Aspek & $\sum \mathrm{X}$ & $\sum \mathrm{Xi}$ & $\begin{array}{l}\mathrm{P} \\
(\%)\end{array}$ & $\begin{array}{c}\text { Kriteria } \\
\text { Kevalidan }\end{array}$ & Ket. \\
\hline \multirow[t]{3}{*}{1} & \multirow[t]{3}{*}{$\begin{array}{l}\text { Ibu Nurma Izzati, } \\
\text { M. Pd }\end{array}$} & Kelayakan Isi & 42 & 48 & 87,5 & Valid & $\begin{array}{c}\text { Tdk } \\
\text { Revisi }\end{array}$ \\
\hline & & $\begin{array}{l}\text { Kelayakan } \\
\text { Penyajian }\end{array}$ & 24 & 24 & 100 & Valid & $\begin{array}{c}\text { Tdk } \\
\text { Revisi }\end{array}$ \\
\hline & & $\begin{array}{l}\text { Kelayakan } \\
\text { Kebahasaan }\end{array}$ & 26 & 28 & 92,9 & Valid & $\begin{array}{c}\text { Tdk } \\
\text { Revisi }\end{array}$ \\
\hline \multicolumn{3}{|c|}{ Jumlah } & 92 & 100 & 92 & Valid & $\begin{array}{c}\text { Tdk } \\
\text { Revisi }\end{array}$ \\
\hline \multirow[t]{4}{*}{2} & \multirow[t]{3}{*}{$\begin{array}{c}\text { Bapak Yandi } \\
\text { Heryandi, M. Pd }\end{array}$} & Kelayakan Isi & 42 & 48 & 87,5 & Valid & $\begin{array}{c}\text { Tdk } \\
\text { Revisi }\end{array}$ \\
\hline & & $\begin{array}{l}\text { Kelayakan } \\
\text { Penyajian }\end{array}$ & 21 & 24 & 87,5 & Valid & $\begin{array}{c}\text { Tdk } \\
\text { Revisi }\end{array}$ \\
\hline & & $\begin{array}{c}\text { Kelayakan } \\
\text { Kebahasaan }\end{array}$ & 26 & 28 & 92,9 & Valid & $\begin{array}{c}\text { Tdk } \\
\text { Revisi }\end{array}$ \\
\hline & Jumlah & & 89 & 100 & 89 & Valid & $\begin{array}{c}\text { Tdk } \\
\text { Revisi }\end{array}$ \\
\hline
\end{tabular}

Tabel 3. Hasil Validasi Ahli Media

\begin{tabular}{cccccccc}
\hline No & Validator & Aspek & $\sum \mathrm{X}$ & $\sum \mathrm{Xi}$ & $\begin{array}{c}\mathrm{P} \\
(\%)\end{array}$ & $\begin{array}{c}\text { Kriteria } \\
\text { Kevalidan }\end{array}$ & Ket. \\
\hline 1 & $\begin{array}{c}\text { Bapak Dr. H. } \\
\text { Darwan, M. Kom }\end{array}$ & $\begin{array}{c}\text { Kelayakan } \\
\text { Kegrafikan }\end{array}$ & 46 & 48 & 95,8 & Valid & $\begin{array}{c}\text { Tdk } \\
\text { Revisi }\end{array}$ \\
2 & $\begin{array}{c}\text { Bapak Hendri } \\
\text { Handoko, M. Pd }\end{array}$ & $\begin{array}{c}\text { Kelayakan } \\
\text { Kegrafikan }\end{array}$ & 46 & 48 & 95,8 & Valid & $\begin{array}{c}\text { Tdk } \\
\text { Revisi }\end{array}$ \\
\hline
\end{tabular}

Hasil pernyataan terbuka pada angket validasi, para ahli memberikan kritikan serta saran diantaranya sub bab materi pada bahan ajar dibuat highlight serta diperjelas pula, kesalahan ataupun kekeliruan dalam penulisan perlu diperbaiki, tambahkan gambar atau tulisan yang lebih merangsang menarik minat untuk pembacanya, libatkan peserta didik dalam menemukan konsep sendiri dengan menyediakan ruang kosong (melengkapi), evaluasi/latihan diberikan untuk tiap sub materi tidak dalam kumpulan, latihan soal tidak terlalu banyak disesuaikan dengan indikator yang ada, serta masukkan nilainilai religius, bahan ajar ini akan disebarkan 
kepada siswa maka saat mencetak bahan ajar sebaiknya menggunakan printer laser agar bahan ajar tersebut dapat bertahan lama.

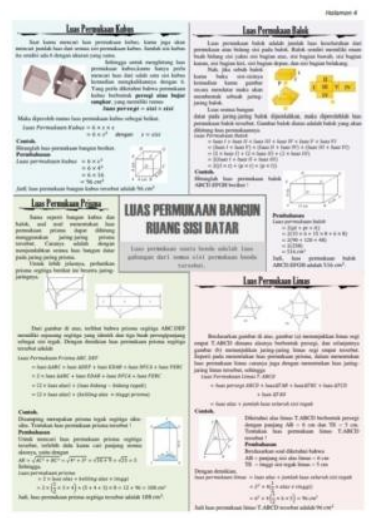

Gambar 1.

Sebelum Revisi

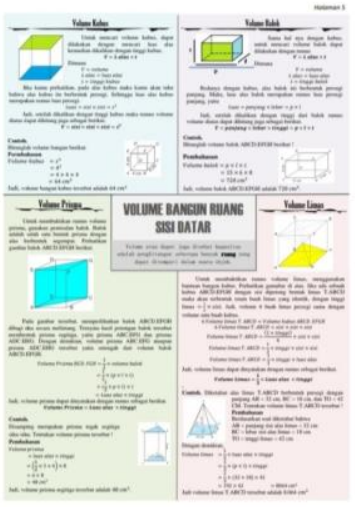

Gambar 3.Sebelum Revisi

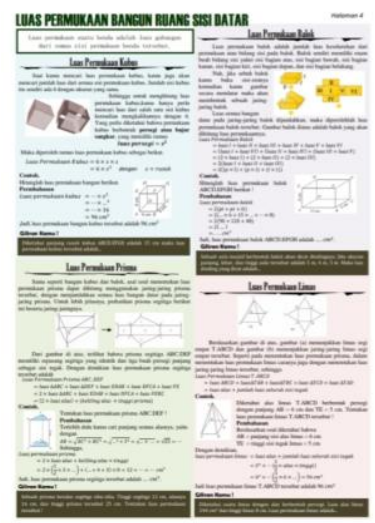

\section{Gambar 2.}

Setelah Revisi

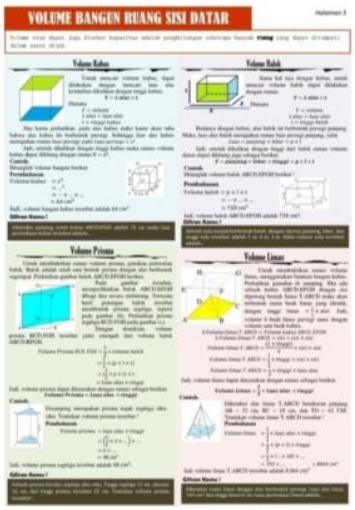

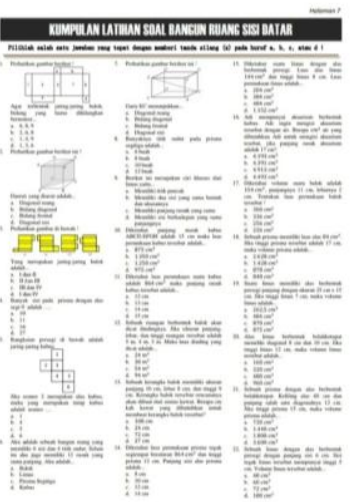

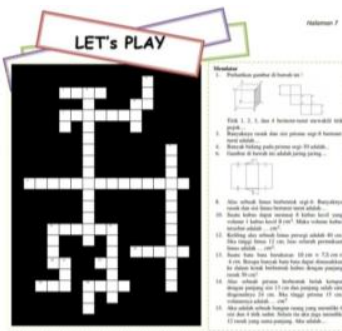

Gambar 5. Sebelum Revisi

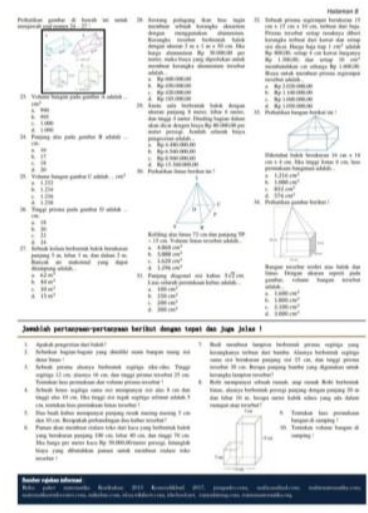

Gambar 7. Sebelum Revisi

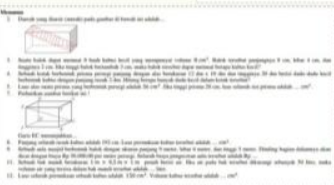

Gambar 6. Setelah Revisi

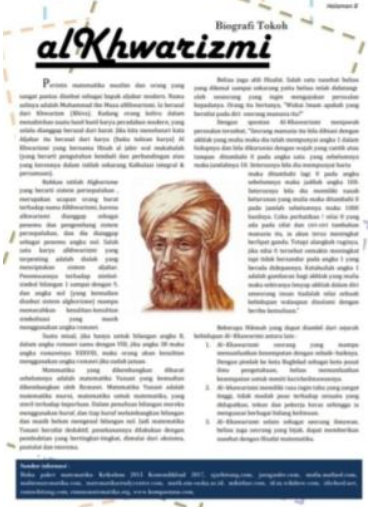

Gambar 8. Setelah Revisi

Tabel 4. Hasil Angket Respon Siswa

\begin{tabular}{ccccccc}
\hline No & Indikator & $\sum \mathrm{X}$ & $\sum \mathrm{Xi}$ & $\mathrm{P}(\%)$ & Kriteria Kevalidan & Ket. \\
\hline 1 & Ketertarikan & 398 & 448 & 88,4 & Valid & Tdk Revisi \\
2 & Materi & 366 & 448 & 81,7 & Valid & Tdk Revisi \\
3 & Bahasa & 305 & 336 & 90,8 & Valid & Tdk Revisi \\
& Jumlah & 1069 & 1232 & 86,8 & Valid & Tdk Revisi \\
\hline
\end{tabular}


Setelah melakukan validasi kepada para hali dan dilakukan perbaikan, penulis mulai menyebar produk bahan ajar kepada siswa yang menjadi objek penelitian. Dari produk bahan ajar yang disebar kepada siswa diperoleh hasil persentase kelayakan bahan ajar mencapai 86,77 \%. Persentase pencapaian tersebut berada pada klasifikasi layak.

Analisis selanjutnya yakni terkait perbandingan motivasi belajar siswa. Setelah dilakukan uji $\mathrm{t}$ independent pada angket motivasi belajar siswa kelas eksperimen dan kelas kontrol, terlihat ringkasan statistik sampel. Pada uji coba penggunaan produk bahan ajar di kelas eksperimen yakni kelas $\mathrm{C}$, diperoleh ratarata motivasi belajar siswa sebesar 124,68, sedangkan pada kelas B sebagai kelas kontrol, dengan bahan ajar yang digunakan adalah lembar kerja siswa memperoleh ratarata motivasi belajar sebesar 116,04. Dengan demikian rata-rata motivasi belajar siswa kelas $\mathrm{C}$ lebih besar dari rata-rata motivasi belajar siswa kelas B. Makna dari perbedaan rata-rata motivasi belajar kedua kelas tersebut dapat dilihat dari output uji t. Pada output uji t terlihat bahwa Sig. (2tailed) menghasilkan angka 0,001. Hasil nilai Sig. (2-tailed) tersebut $<0,05$. Hal ini menunjukkan bahwa $H_{0}$ ditolak dan
$H_{1}$ diterima, artinya terdapat perbedaan yang signifikan antara motivasi belajar kelas C dan kelas B. Dengan demikian, dapat disimpulkan bahwa motivasi belajar siswa menggunakan produk pengembangan bahan ajar lebih baik dari motivasi belajar siswa menggunakan bahan ajar lembar kerja siswa.

\section{KESIMPULAN DAN SARAN}

Berdasarkan penelitian yang telah dilakukan, maka dapat disimpulkan:

(1) Produk pengembangan bahan ajar bentuk surat kabar pada penelitian ini menggunakan model pengembangan ADDIE yang merupakan kepanjangan dari Analysis, Design, Development, Implementation, dan Evalution. Prodak bahan ajar yang dihasilkan berupa bahan ajar matematika dalam bentuk surat kabar berukuran tabloid $(27,94 \mathrm{~cm} \mathrm{x}$ $43,18 \mathrm{~cm}$ ) yaitu setengah ukuran dari broadsheet, agar produk dapat lebih mudah dibawa dan digunakan oleh peserta didik, memiliki 8 halaman. Hasil penilaian memperoleh persentase kelayakan materi sebesar 90,5\% dan kelayakan desain sebesar 95,83\%, serta berdasarkan respon siswa memperoleh persentase kelayakan $86,77 \%$. Dengan demikian, prodak pengembangan berupa 
bahan ajar bentuk surat kabar ini layak untuk digunakan dalam proses pembelajaran.

(2) Berdasarkan output uji t independent terlihat bahwa Sig. (2-tailed) menghasilkan angka 0,001. Hasil nilai Sig. (2-tailed) tersebut $<0,05$, maka $H_{0}$ ditolak dan $H_{1}$ diterima, yang artinya terdapat perbedaan yang signifikan antara motivasi belajar kelas $\mathrm{C}$ dan kelas B. Dengan demikian disimpulkan bahwa motivasi belajar siswa menggunakan produk pengembangan bahan ajar lebih baik dari motivasi belajar siswa menggunakan bahan ajar lembar kerja siswa.

\section{Saran}

Berdasarkan hasil penelitian ini, dapat disampaikan beberapa saran berikut:

1. Produk pengembangan bahan ajar matematika bentuk surat kabar yang dikembangkan oleh peneliti hanya sebagai bahan ajar pendukung buku ajar yang sebelumnya sudah ada.

2. Produk pengembangan bahan ajar bentuk surat kabar pada mata pelajaran matematika untuk bab lain perlu dikembangkan karena pada pembelajaran bangun ruang sisi datar telah terbukti efektif untuk digunakan karena mampu meningkatkan motivasi belajar siswa.

3. Produk pengembangan bahan ajar matematika bentuk surat kabar dapat digunakan guru sebagai rujukan untuk mengembangkan bahan ajar yang menarik dan sesuai dengan karakter siswa.

\section{DAFTAR PUSTAKA}

Ammi Fauziah, A. R. (2017). Hubungan antara Motivasi Belajar dengan Minat Belajar Siswa Kelas IV SDN Gaga 05 Kota Tangerang. JURNAL JPSD. Vol. 4 (1). pp. 48-53.

Consuelo G Sevilla, J. A. (2006). Pengantar Metode Penelitian. Jakarta: UIPress.

Depdiknas. (2008). Pengembangan Bahan Ajar.

Gewati, M. (2018). Kemampuan Matematika Siswa Indonesia Memprihatinkan, Solusinya?. Diakses dari: https://lifestyle.kompas.com/read/20 18/03/21/09211381/kemampuanmatematika-siswa-indonesiamemprihatikan-solusinya $\quad\left[\begin{array}{ll}7 & \text { Mei }\end{array}\right.$ 2019].

Kumaidi, B. m. (2014). Pengantar Metode Statistika. Cirebon: Eduvision Publishing.

Lestari, I. (2013). Pengembangan Bahan Ajar Berbasis Kompetensi. Padang: Akademia Permata.

Prastowo, A. (2016). Pengembangan Bahan Ajar Tematik. Jakarta: Kencana. 
Riono, A. (2016). Pengambangan Bahan Ajar Fiqih Model Majalah Anak Materi Thaharah untuk Meningkatkan Keefektifan Hasil Belajar Siswa Kelas I Madrasah Ibtidaiyah Negeri Malang 2. Skripsi. Tidak dipublikasikan. Malang: UIN Maulana Malik Ibrahim.

Sugiyono. (2017). Metode Penelitian Kuantitatif, Kualitatif, dan $R \& D$. Bandung: Alfabeta.

Suprihatin, S. (2015). Upaya Guru dalam Meningkatkan Motivasi Belajar Siswa. Jurnal Pendidikan Ekonomi UM Metro. Vol. 3 (1). pp. 73-82. 